\title{
Strategi Branding Jakone Mobile Melalui Sinergi BUMD Taman Jajan Jakone Mobile Thamrin 10
}

\author{
Fauzia, Firman Kurniawan Sujono \\ Pasca Sarjana Ilmu Komunikasi Universitas Indonesia, Kampus Salemba, Gedung IASTH, Jl. \\ Salemba Raya No. 4, Jakarta, Indonesia \\ fauziaiskandar09@gmail.com, firmankurniawan@yahoo.com
}

Masuk tanggal : 08-01-2020, revisi tanggal : 11-05-2020, diterima untuk diterbitkan tanggal : 30-06-2020

\begin{abstract}
The development of technology made many of the banking industry and companies began to develop cash payment systems using barcodes. Bank DKI as the Regional Government Bank of the Capital City of Jakarta provides JakOne Mobile products as a mobile banking and mobile wallet application. The feature of this application is the payment system via barcode scan. The intense competition in DKI Jakarta makes Bank DKI must find ways to compare its products, one of which is the acquisition of a payment system in Thamrin 10. Thamrin 10 is a culinary district, Thamrin 10 which is opened in accordance with the designation made by the Synergy of DKI Jakarta BUMD. The researcher wants to know the Branding efforts undertaken by the DKI Bank through Thamrin 10 whether with the synergy of BUMD increases the level of Jakarta people's knowledge of JakOne Mobile and increases the use of the application. This study uses descriptive qualitative research methods with case studies of JakOne Mobile users. The data collection techniques using interviews, observation and data obtained from the news. The results of interviews and primary data obtained did indeed increase active users in December 2019 and with the presence of Thamrin 10 is an opportunity for Bank DKI to introduce products so that the people of Jakarta become more familiar with Bank DKI products. By involving DKI Bank in the cashless payment system in Thamrin 10, change the picture of the Regional Bank which is often considered to be canceled in terms of technology.
\end{abstract}

Keywords: application, branding, mobile wallet, synergy

\begin{abstract}
Abstrak
Berkembangnya teknologi membuat banyak dari industri perbankan dan perusahaan startup untuk mengembangkan sistem pembayaran cashless menggunakan barcode. Bank DKI sebagai Bank Pemerintah daerah milik Ibu Kota Jakarta memberikan produk JakOne Mobile sebagai aplikasi mobile banking dan mobile wallet. Fitur dari aplikasi tersebut merupakan sitem pebayaran melalui scan barcode. Ketatnya persaingan khususnya di DKI Jakarta membuat Bank DKI harus mencari cara untuk memBranding produknya, salah satunya adalah mengakusisi sistem pembayaran di Thamrin 10. Thamrin 10 merupakan distrik kuliner, Thamrin 10 dibuka atas dasar perwujudan Sinergi BUMD DKI Jakarta. Peneliti ingin mengetahui usaha Branding yang dilakukan oleh Bank DKI melalui Thamrin 10 apakah dengan adanya sinergi BUMD membut peningkatan dalam segi produk knowledge masyarakat Jakarta terhadap JakOne Mobile dan peningkatan penggunaan aplikasi tersebut. Penelitian ini menggunakan metode penelitian kualitatif deskriptif dengan pendekatan studi kasus pengguna JakOne Mobile. Adapun teknik pengumpulan data menggunakan wawancara, observasi dan data-data yang didapat dari pemberitaan.
\end{abstract}


Dari hasil wawancara dan dara primer yang didapat memang adanya peningkatan pengguna aktif pada bulan Desember 2019 serta dengan adanya Thamrin 10 merupakan kesempatan Bank DKI untuk memperkenalkan produk sehingga masyarakat Jakarta menjadi lebih paham atas produk Bank DKI. Dengan terlibatnya Bank DKI dalam sistem pembayaran cashless di Thamrin 10 maka merubah image dari Bank Daerah yang sering dianggap terlambat dalam hal teknologi.

Kata Kunci: aplikasi, branding, mobile wallet, sinergi

\section{Pendahuluan}

Teknologi komunikasi terus berkembang pesat, terutama dengan adanya internet sehingga menyebabkan "jarak psikologis" mendekatkan "jarak geografis" antar bangsa (Suri 2019). Teknologi telah berkembang dan menjadi suatu momok bagi semua sektor industri termasuk industri perbankan. Munculnya teknologi pembayaran non - tunai yang didukung oleh Bank Indonesia untuk menciptakan transaksi cashless sehingga mendorong banyaknya muncul aplikasi mobile wallet baik dari pihak perbankan atau pun non perbankan. Mobile wallet sendiri merupakan salah satu produk dari teknologi pembayaran elektronik. Bank Indonesia dalam Peraturan Bank Indonesia No. 20/6/PBI/2018 tentang Uang Elektronik telah mengatur terkait dengan penyedia payment gateway yaitu pembayaran elektronik. Pertanggal 24 Mei 2019, terdapat 38 penyelenggara jasa sistem pembayaran yang telah memperoleh izin dari Bank Indonesia (Informasi Perizinan Penyelenggara dan Pendukung Jasa Sistem Pembayaran 2019). Dari 38 yang memperoleh izin terdapat 11 produk yang dimiliki oleh perbankan salah satunya adalah JakOne Mobile yang merupakan aplikasi mobile banking dari Bank DKI yang di dalamnya terdapat menu JakOne Pay yang merupakan produk dari mobile wallet nya. JakOne Mobile adalah aplikasi layanan keuangan yang terdiri dari mobile banking dan mobile wallet yang dapat digunakan untuk melakukan transaksi kebutuhan sehari-hari pada merchant-merchant yang bekerjsama dengan Bank DKI, pendaftaran sekaligus pembukaan rekening baru hingga aktivasi kartu dan PIN (BankDKI 2017). Sistem yang digunakan adalah scan barcode untuk pembayaran. JakOne mobile masuk pada karegori mobile wallet atau e-money karena menggunakan server based.

Bank DKI merupakan Bank Umum Milik Daerah yang kepemilikan sahamnya dimiliki oleh Pemerintah Provinsi DKI Jakarta dengan besaran 99,77\% milik Pemprov DKI dan 0,03\% milik PD. Pasar Jaya. JakOne Mobile diluncurkan pada tanggal 29 Agustus 2017 dan diresmikan oleh Gubernur DKI Jakarta saat itu yaitu Djarot Syaiful Hidayat, aplikasi tersebut dapat digunakan oleh nasabah ataupun non nasabah Bank DKI untuk melakukan transaksi seperti top up JakCard atau JakLingko, biller Telkom PSTN dan tagihan air, listrik PLN, pembayaran tiket, TV berlangganan, retribusi daerah, e-Samsat dan pembayaran tagihan pulsa prabayar serta pascabayar melalui smartphone (BankDKI 2017). Bank DKI sendiri merupakan Bank BUMD dimana hampir seluruh sahamnya merupakan milik Pemerintah Provinsi DKI Jakarta. Atas dasar tersebut taget pasar utama dari Bank DKI merupakan masyarakat DKI Jakarta terutama Pegawai Negeri Sipil dan BUMD di lingkungan DKI Jakarta karena dari fiturnya JakOne Mobile memberikan 
Fauzia, Firman Kurniawan Sujono: Strategi Branding Jakone Mobile Melalui Sinergi BUMD Taman Jajan Jakone Mobile Thamrin 10

kemudahan dalam pembayaran pajak dan retribusi. Fitur dan tujuan dari produk JakOne Mobile selaras dengan tujuan dari pemerintah DKI Jakarta dalam mewujudkan cashless society. Pemerintah Daerah DKI Jakarta berupaya mewujudkan cashless society dengan tujuan agar dapat memudahkan pelacakan transaksi dengan menggunakan alat pembayaran digital masyarakat dapat mengendalikan pengeluaran, selain itu pencatatan transaksi non tunai akan memudahkan pemerintah daerah dan nasional untuk mengetahui berbagai aspek perekonomian seperti transaksi jual beli yang terjadi di wilayah pemerintahannya, mengawasi transaksi keuangan vital, hingga lelang pengadaan barang. Sehingga pengawasan atas angka penyelewengan dana dan transaksi ilegal menjadi lebih mudah. Selain itu pemerintah DKI beranggapan bahwa membawa alat pembayaran dalam bentuk kartu tentu lebih aman dari pada membawa uang tunai. Pemerintah DKI memiliki beberapa program bantuan sosial yang dilakukan dalam bentuk kartu yaitu Kartu Jakarta Lansia, Kartu Jakarta Pintar dan lain-lain sehingga diharapkan dengan bantuan dalam bentuk nontunai dapat lebih tepat sasaran (JSC 2017).

Dalam persaingan produk mobile wallet, fitur dan benefit serta akses mudah untuk dapat digunakan dimana saja, kapan saja dan jaringan kerjasama yang luas membuat penyedia jasa sistem pembayaran berlomba-lomba untuk menarik minat pengguna. Promosi yang saat ini sangat trend adalah program cashback. Seiring berkembangnya teknologi $e$-wallet promosi dengan mengedepankan kata 'diskon' sudah mulai ditinggalkan dan digantikan dengan promo cashback untuk menarik pengguna mobile wallet untuk menarik pelanggan. Cashback merupakan salah satu bentuk promosi dengan menawarkan pembeli dapat memperoleh presentase pengembalian uang tunai ataupun uang virtual dengan syarat tertentu yang telah ditentukan oleh penyelengara promo cashback. Promo cashback tersebut yang diharapkan menjadi daya tarik dari penggunaan aplikasi sebagai alat pembayaran. JakOne Mobile menggunakan strategi promosi tersebut dimana terdapat beberapa promo seperti Cashback Rp 5.000,- setiap hari (minimal pembelanjaan diatas Rp 15.000,- cashback $50 \%$ di hari-hari tertentu dibeberapa merchant yang sudah bekerjasama seperti Gramedia, McD, KFC dan lain-lain, dana cashback akan masuk kembali ke mobile wallet dan pengguna dapat menggunakannya untuk transaksi pembayaran lainnya. Dengan promo, fitur dan benefit yang ada, diharapkan JakOne Mobile dapat meningkatkan jumlah transaksi pengguna tidak hanya nasabah Bank DKI saja akan tetapi non nasabah hingga ke level nasional. Ketatnya persangain mobile wallet atau aplikasi layanan dompet digital membuat aplikasi harus memberikan inovasi baru dan memberikan keuntungan serta kemudahan kepada pengguna. 


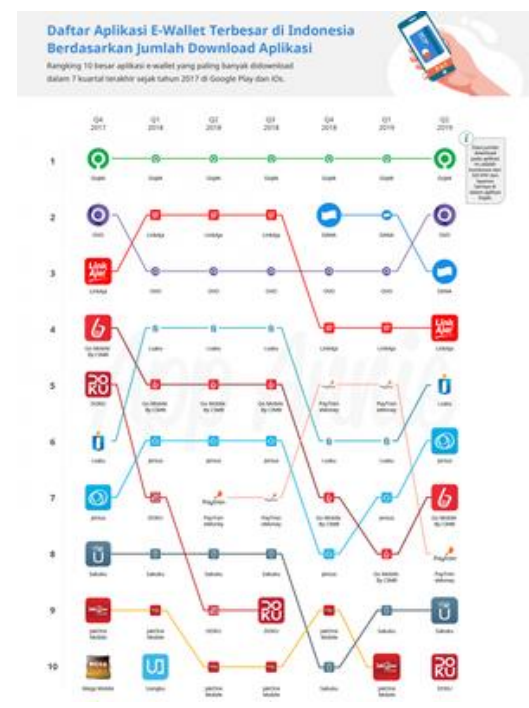

Gambar 1: Daftar E-Wallet Terbesar Di Indonesia Berdasarkan Jumlah Donwoader Aplikasi Sumber:iprice.co.id (Devita 2019)

Pada kuartal satu tahun 2019, aplikasi JakOne Mobile masuk dalam 10 layanan dompet digital di Indonesia yang paling poluler akan tetapi pada kuartal dua 2019 JakOne Mobile tergeser dengan ketatnya persaingan layanan dompet digital (Kompas.com 2019). Penguatan brand JakOne Mobile tidak hanya dilakukan dengan cara promosi saja, akan tetapi toko atau merchant yang menerima pembayaran melalui JakOne Mobile juga menjadi salah satu usaha dalam meningkatkan penggunaan aplikasi tersebut. Selain bekerjasama dengan beberapa instansi untuk kanal pembayaran, Bank DKI selaku produk owner dari JakOne Mobile bekerjasama dalam Sinergi BUMD DKI Jakarta bersama dengan PD. Pasar Jaya dan PD. Pal Jaya pada pembuatan Thamrin 10 yang merupakan taman kuliner dengan 54 tenant makanan dan taman kreatif. PD. Pasar Jaya bertindak sebagai pengelola food and creative park, Bank DKI berperan sebagai sistem pembayaran dan PD. Pal Jaya hadir dalam penyediaan toilet umum bersih. Thamrin 10 berlokasi di Jl. M.H Thamrin, dengan lokasi yang sangat strategis taman yang di resmikan oleh Gubernur DKI Jakarta Anies Baswedan pada tanggal 20 Desember 2019 tidak pernah sepi pengunjung. Sistem Pembayaran yang diterapkan pada Thamrin 10 adalah cashless dengan JakCard ataupun pembayaran melalui scan barcode Bank DKI yang dapat dilakukan melalui JakOne Mobile dan aplikasi mobile wallet lainnya. Pada Thamrin 10 memang Bank DKI banyak memberikan promosi dan iklan untuk penggunaan sistem pembayaran melalui JakCard atau pun JakOne Mobile.

Peneliti memilih JakOne Mobile dari Bank DKI sebagai unit analisis karena dari 38 penyedia jasa sistem pembayaran terdapat dua produk yang berasal dari Bank Daerah yaitu Bank DKI dan Bank Jateng, hal tersebut menjadi isu menarik ketika Bank Daerah atau BUMD bersaing dengan perusahaan yang berkelas nasional bahkan internasional. Ketika sebuah BUMD dapat bersaing dengan perusahaan dengan level yang lebih luas maka perekonomian daerah akan tumbuh 
Fauzia, Firman Kurniawan Sujono: Strategi Branding Jakone Mobile Melalui Sinergi BUMD Taman Jajan Jakone Mobile Thamrin 10

dan akan menjadi tolak ukur bagi Bank-bank daerah lainnya. Selain itu ditengah persaingan mobile wallet yang ketat khususnya di DKI Jakarta membuat peneliti ingin mengetahui apakah brand dari Bank DKI khususnya produk mobile wallet JakOne Mobile sudah kuat kalangan masyarakat Jakarta atau sebaliknya. Dengan adanya taman kuliner Thamrin 10 peneliti berhipotesis bawa food park berkonsep cashless tersebut dapat meningkatkan brand equity dari JakOne Mobile.

Pada penelitian sebelumnya, yang dilakukan oleh Ellena Nurfaiza. H pada thesisnya yang berjudul Analsisi Peran Program Corporate Social Responsibility (CSR) dalam Membangun Corporate Reputation, Brand Equity dan Social Euity Brand: Studi Kasus Pada Merek Lifebuoy Produk dari PT. Unilever (Nurfaiza 2012) lebih meninjau dari sisi manajemen bisnis dengan mukur antara reputasi yang berpengaruh signifikan terhadap brand equity melalui strategi CSR. Selain itu banyak dari penelitian sebelumnya yang membahas $e$-walet dari segi penerimaan pengguna dan kepercayaan pengguna salah satunya adalah penelitian yang dilakukan oleh Elsa Sialaen dan Bulan Prabawani yang meneliti terkait pengaruh peneriman pengguna dan persepsi manfaat terhadap minat pembelian saldo $e$-walet OVO (Silaen and Prabawani 2019). Pada penelitian ini, peneliti bertujuan untuk meninjau strategi Branding yang dilakukan oleh Bank DKI terhadap JakOne Mobile melalui sinergi BUMD yaitu mengakusisi sistem pembayaran yang ada di Thamrin 10.

\section{Branding}

Brand atau merek menurut American Marketing Association merupakan nama, istilah, tanda, lambang, atau desain, atau kombinasinya, yang dimaksudkan untuk mengidentifikasikan barang atau jasa dari salah satu penjual atau kelompok penjual dan mendiferensiasikan mereka dari para pesaing (Kotler and Keller 2009). Sedangkan peran brand di dalam sebuah pemasaran adalah sebagai perangkat pengingat (Peter and Olson 2000). Brand dengan nama dan logo yang sangat futuristic belum tentu dapat melekat pada ingatan konsumen, sebuah brand harus kredibel dan mengindikasikan kategori yang terhubung dengan produk yang di labelinya. Bagaimana merek dapat menandakan bahan dari produk ataupun tipe dari calon konsumen/pasar yang dituju (Kotler and Keller 2009). Banyak hal yang harus dimiliki oleh sebuah brand produk yang pada dasarnya harus dapat diingat sehingga sangat mudah dikenali oleh pasar, hal estetika dari brand juga harus menjadi salah satu unsur yang menjadi sasaran dalam pembuatan brand. Adapun indikator brand yaitu dapat diingat, bermakna, disukai, dapat diubah, dapat di adaptasi dan dapat dilindungi (Kotler and Keller 2009).

Fungsi brand di dalam sebuah perusahaan juga harus membangun persepsi terhadap kualitas dari produk yang dipasarkan. Proses pengambilan keputusan untuk membeli suatu produk dimulai dari pengenalan masalah, pencarian informasi, evaluasi terhadap beberapa alternatif, yang seanjutnya akan tercipta suatu keputusan pembelian dan terbentuknya perilaku pasca pembelian (Kotler 2003). Maka dari itu brand memiliki peran penting dalam sebuah pemasaran. Praktisi pemasaran dan peneliti telah berupaya menentukan faktor-faktor yang menentukan kualitas nama merek, sehingga adanya kesepakatan umum bahwa 
nama merek harus memenuhi beberapa persyaratan mendasar yaitu (A. Shimp, Terence, and J. Craig 2013):

1. Nama merek yang baik harus membedakan merek dari penawaran yang kompetitif.

2. Harus memfasilitasi pembelajaran konsumen dari asosiasi merek yang diinginkan dengan menggambarkan atau menyarankan atribut atau manfaat merek.

3. Penting bahwa nama tersebut mencapai kompatibilitas dengan gambar yang diinginkan merek dan dengan desain dan kemasan produknya.

4. Nama yang mudah diingat dan mudah diucapkan dan dieja.

Branding berdasarkan sudut pandang akademis merupakan sebuah proses dalam mendesign sebuah brand atau merek termasuk logo, nama, identitas, brand awareness dan brand image melalui berbagai strategi pemasaran termasuk iklan, packaging dan desain produk (Boomsma, Marije, and Arnoldus 2008). Kesadaran merek merupakan kemampuan konsumen dalam mengidentifikasi merek dalam kondisi yang berbeda (Oktavianti and Utami 2019). Pentingya menciptakan brand awareness dari konsumen, sehingga konsumen dapat mengidentifikasi suatu brand dalam suatu kondisi, tugas dari pemasaran adalah mengenalkan brand dan mengingatkannya kembali kepada pasar/konsumen. Salah satu strategi pemasaran yang ditawarkan oleh Keller adalah dengan memberi treatment kepada konsumer melalui paparan berulang sehingga konsumen merasa mengenal merek tersebut (Keller 2003).

Selain brand awareness, brand image juga mendukung dalam proses pemasaran dan mempengaruhi keputusan membeli konsumen. Brand image atau citra merek merupakan hasil persepsi dan pemahaman konsumen terhadap suatu brand. Citra brand sendiri dapat dibentuk dengan cara mengkomunikasikan sebuah brand kepada konsumen atau pasar. Brand harus memiliki nilai menarik dari sekedar pemenuhan kebutuhan konsumen, dan juga harus melebihi fungsi serta fitur produk yang ditawarkan.

\section{Brand Equity}

Brand equity digunakan untuk menunjukkan seberapa kuat brand di masyarakat. Banyak faktor yang dapat mempengaruhi brand equity seperti harga, distribusi, kualitas, marketing (iklan), fitur dan benefit. Harga suatu merek sering menunjukkan sesuatu tentang kualitas atau manfaat suatu produk (Huber, Shao, and Bao 2007), biasanya brand menciptakan asosiasi di benak konsumen (Keller 2003). Boulding dalam penelitiannya mengungkapkan bahwa iklan sering kali menciptakan brand equity sedangkan promosi penjualan memiliki kecenderungan mengurangi brand equity.

Di dalam penelitiannya Huber, Shao dan Bao (2007), brand equity dapat ditingkatkan dengan cara mix marketing dengan catatan bahwa ada beberapa hal yang harus ditekankan diantaranya adalah distribusi, pengalaman dan pemilihan iklan. Distribusi memiliki dampak yang besar dalam menciptakan equitas, karena ketika konsumen dapat menemukan produk dengan mudah dan tersedia ketika dibutuhkan (Aaker 1996). Dalam meningkatkan brand equity perusahaan juga 
Fauzia, Firman Kurniawan Sujono: Strategi Branding Jakone Mobile Melalui Sinergi BUMD Taman Jajan Jakone Mobile Thamrin 10

harus mengedepankan pengalaman pelanggan, ketika produk yang dibelikan memberikan kepuasan maka hal tersebut akan menjadi sumber yang kuat bagi pelanggan untuk mengembangkan makna brand. Brand equity dinyatakan dalam kesediaan individu untuk membentuk ikatan emosional, kognitif dan konatif dengan produk (Huber, Shao, and Bao 2007). Semakin kuat ikatan, semakin besar kemungkinan konsumen untuk membeli merek (Rossiter and Percy 1987).

Di jaman modern ini, masyarakat dipaparkan banyak informasi (TIK jenuh) sehingga perusahaan dituntut harus pandai dalam mengelola mix marketing yang dapat mempengaruhi brand equity walaupun efeknya dapat secara positif ataupun negatif (Huber, Shao, and Bao 2007). Media pemasaran yang sering digunakan oleh perusahaan adalah iklan. Di beberapa sektor, jenis dan isi pesan iklan dapat berkontribusi signifikan terhadap ekuitas merek, sedangkan di sektor lain kecanggihan teknis produk mungkin yang paling penting (Dawar and Parker 1994). Terdapat lima kategori dasar dari Brand Equity menurut Aaker yaitu kesadaran merek, asosiasi merek, persepsi kualitas dan aset-aset lainnya (Aaker 1996). Brand equity sangat dipengaruhi oleh citra brand dan bagaimana pemasaran terus mempromosikan suatu brand dan memberikan inovasi baru sehingga konsumen akan menjadikan brand dan produknya sebagai pilihan utama dalam memenuhi kebutuhannya.

\section{Integrated Marketing Communication (IMC)}

Integrated Marketing Communication (IMC) adalah koordinasi elemen bauran promosi (periklanan, hubungan masyarakat, promosi penjualan, penjualan pribadi, pemasaran langsung, dan pemasaran online / sosial media) dengan satu sama lain dan dengan elemen lain dari bauran pemasaran merek (produk, tempat, harga) sedemikian rupa sehingga semua elemen berbicara dengan satu suara (Juska 2017). Shimp menjelaskan terdapat lima fitur dalam memahami dan mengimplementasikan IMC dalam praktisi (T. A. Shimp 2003), sebagai berikut:

1. IMC harus dimulai dengan customer, hal tersebut dilakukan untuk menentukan metode yang paling tepat dan efektif untuk mengembangkan program komunikasi persuasif. Konsumen memiliki kontrol dan kendali atas pemasaran yang terjadi. Penggunaan iklan pada media massa tradisional sudah dianggap tidak relevan saat ini, media massa tradisional mulai tergantikan dengan media promosi berbasis internet.

2. Menggunakan segala bentuk jaringan yang relevan dan memanfaatkan segala bentuk media yang dapat digunakan dalam menjangkau sasaran pelanggan. Brand harus bisa menyentuh sasaran pelanggan dengan berada di sekitar mereka atau memberikan pelanggan paparan iklan secara terus menerus atau dapat disebut dengan 360-degree Branding.

3. Bicara dengan satu suara, koordinasi dalam pesan dan media sangat penting untuk mencapai brand image yang kuat dan dapat menggerakkan konsumen untuk bertindak.

4. Membangun hubungan antara merek dan pelanggan, membangun hubungan yang sukses antara pelanggan dan merek menyebabkan pembelian berulang dan menciptakan loyalitas terhadap suatu merek. 
Dapat mempengaruhi perilaku, program loyalitas merupakan metode yang paling banyak digunakan untuk membangun hubungan dengan konsumen, hal ini digunakan dengan tujuan untuk menciptakan pelanggan yang berkomitmen pada brand dan mendorong mereka untuk memenuhi kebutuhan mereka dengan produk dan layanan dari perusahaan yang memberikan menawarkan. Selain itu menciptakan pengalaman dengan kesan positif dapat dilakukan dengan membuat acara khusus atau mengembangkan tempat-tempat menarik yang dapat membangun sensansi bahwa brand sponsor relevan dengan kehidupan dan gaya hidup konsumen (T. A. Shimp 2003).

\section{Mobile Wallet}

Penelitian ini menggunakan konsep mobile wallet dimana mobile wallet dikategorikan sebagai mobile payment. Mobile wallet merupakan yang termasuk transaksi non-tunai, tidak menggunakan media seperti kartu, dan melakukan transaksi melalui kanal elektronik (Amoroso and Magnier-Watanabe 2012). Mobile wallet merupakan layanan elektronik money atau e-money dengan telepon genggam atau device lainnya yang bersifat mobile. Lembaga bank hingga non-bank berlomba-lomba membuat produk mobile wallet untuk dijual kepasaran. Lingkungan mobile wallet akhirnya semakin ramai dan semakin banyaknya kompetitor membuat persaingan di dunia mobile wallet semakin sengit. Semakin berkembangnya zaman mobile wallet semakin digemari tidak hanya kemudahan dalam bertransaksi mobile wallet kini sudah bekerjasama dengan hampir selutuh toko atau merchant di pusat perbelanjaan, e-commerce dan situs-situs pembelian lainnya sehingga banyak dari masyarakat memilih untuk bertransaksi melalui mobile wallet. JakOne Mobile dari Bank DKI merupakan salah satu aplikasi mobile payment yang di dalamnya tidak hanya menyediakan fitur transaksi perbankan akan tetapi adanya fitur-fitur pembayaran dengan sistem scan by QR.

\section{Metode Penelitian}

Metode penelitian yang digunakan dalam penelitian ini adalah kualitatif dengan metode studi kasus yang disajikan secara deskriptif. Peneliti membentuk dan menyempurnakan konstuk sambil memeriksa data dan mengajukan pertanyaan teoritis tentang data. Dalam kualitatif operasionalisasi mendahului konseptualitasi sehingga ide dan bukti saling bergantung (Neuman 2016). Dalam pengumpulan data peneliti melakukan observasi dan wawancara mendalam dengan penjual yang berjualan di Thamrin 10 dan pengunjung dari Thamrin 10. Peneliti membuat daftar pertanyaan sebagai guide line dari wawancara. Adapun data berupa jumlah user dan jumlah pengunjung dari Thamrin 10 akan menjadi data primer untuk memperkuat temuan peneliti.

Dalam pengumpulan data peneliti melakukan wawancara mendalam pada pihak sales JakOne Mobile di Thamrin 10 sebanyak dua orang, penjual yang berjualan di Thamrin 10 sebanyak dua orang dan pengunjung dari Thamrin 10 sebanyak tiga orang (dari kelompok pengunjung yang berbeda). Peneliti membuat daftar pertanyaan sebagai guide line dari wawancara, selain itu peneliti juga melalukan observasi di Thamrin 10 dan turut menggunakan Aplikasi JakOne 
Fauzia, Firman Kurniawan Sujono: Strategi Branding Jakone Mobile Melalui Sinergi BUMD Taman Jajan Jakone Mobile Thamrin 10

Mobile. Adapun data berupa jumlah user dan jumlah pengunjung dari Thamrin 10 menjadi data tambahan untuk memperkuat temuan peneliti. Data jumlah pengunjung diperoleh dari data yang dipaparkan pada berita online dan jumlah user JakOne Mobile peneliti peroleh dari Annual Report Bank DKI yang diakses melalui website resmi PT. Bank DKI.

\section{Hasil Penemuan dan Diskusi}

Bila dianalisis strategi Branding yang dilakukan oleh Bank DKI terhadap produk aplikasi mobile wallet JakOne Mobile, Bank DKI cenderung mempromosikan produk JakOne Mobile melalui media sosial Instagram dan YouTube. Selain itu poster-poster dari penggunaan JakOne Mobile memang diletakkan disetiap merchant yang bekerjasama dengan pihak Bank DKI. Bila ditelaah dari respon pada komentar di PlayStore dan AppStore memang rating yang diberikan oleh pen-download tidak buruk berkisar 3,7 -3,8 dari skala 5, akan tetapi kurangnya respon dari humas Bank DKI atas keluhan dari pengguna JakOne Mobile sehingga hal tersebut dapat mempengaruhi reputasi dari produk. Pada tanggal 9 Desember 2019 pada AppStore aplikasi JakOne Mobile mendapatkan review dari downloader Ijembet yang menyatakan bahwa kode OTP tidak terkirim untuk mengaktifkan aplikasi dan belum mendapatkan respon dari developer aplikasi. Sedangkan pada PlayStore pada bulan Desember 2019 keluhan terbanyak terkait kode OTP tidak terkirim sehingga tidak dapat aktivasi, salah satunya pada tanggal 25 Desember 2019 yaitu review dari Zakharia Rand yang menegeluhkan:

"otpnya kagak masuk, hadeh sekelas BUMD bikin aplikasi kaya gini."

Atas review tersebut belum ada respon dari pihak Bank DKI. Dari pernyataan tersebut dengan menyatakan 'sekelas' BUMD maka ada harapan besar dari masyarakat dan anggapan bahwa BUMD dapat memiliki produk yang bersaing dengan produk perbankan lain baik BUMN ataupun Swasta Peneliti mencoba mengkonfirmasi kepada Sdr H erkait kode OTP yang tidak terkirim:

Kode OTP sering tidak kekirim itu karena pengguna gak punya pulsa telepon mbak, karena kan itu dikirim lewat SMS jadinya kalo gak ada pulsa gak akan kekirim. Banyak yang protes sih kenapa harus pakai pulsa, sudah dikasi pengertian juga Namanya pengguna maunya gampang, jadi sering sudah pada download gak lanjut aktivasi karena itu (H, komunikasi personal 29 Desember 2019).

Bank DKI selaku Bank yang dinaungi oleh Pemerintah DKI Jakarta memang memiliki peluang besar dalam memfasilitasi sistem pembayaran pada pemerintah daerah serta payroll dari Pegawai Pemerintah Provinsi DKI Jakarta, sehingga pada kalangan pemerintahan di Jakarta produk dari Bank DKI memang sudah dikenal. Selain itu Bank DKI juga bekerjasama dengan beberapa instansi dan e-commerce untuk kanal pembayaran melalui JakOne Mobile seperti PLN, Samsat, PAM, retribusi daerah, BPJS, Tokopedia dan Agoda. Pada review di AppStore tanggal 19 Agustus 2019 Fiqi Oktarias Febrian memberikan review sebagai berikut: 
Aplikasi yg sangat menguntungkan. Bukan warga DKI kalau tidak install JakOne Mobile!!!

Beberapa fitur dari aplikasi JakOne Mobile memang sangat tersegmentasi bagi warga Jakarta seperti pembayaran retribusi daerah, sehingga fitur tersebut dapat mempermudah warga Jakarta dalam bertransaksi. Terhadap sinergi BUMD pada Thamrin 10, Bank DKI mengakusisi 54 tenant makanan (seluruh tenant yang berjualan di Thamrin 10) terkait metode pembayaran yang mengharuskan pengunjung untuk menggunakan JakOne Mobile dan JakCard. Pada Kawasan Thamrin 10 Bank DKI memang melakukan pemasaran dengan cara menaruh banner promosi, stand booth untuk pengisian JakCard dan JakOne Mobile serta petugas untuk menjelaskan produk, dengan adanya akusisi sistem pembayaran memang membuat peningkatan penggunaan dari JakOne Mobile. Terget yang diperkirakan pada akhir tahun 2019 pengguna JakOne Mobile mencapai satu juta pengguna, pada pertengahan April 2019 jumlah pengguna JakOne Mobile sudah mencapai 350.000 pengguna (EQ 2019). JakOne Mobile menyasar segmentasi pasar milenial dan masyarakat dari berbagai lapisan sehingga merchant yang bekerjasama dengan Bank DKI terkait pembayaran melalui JakOne Mobile juga tersebar baik tradisional merchant hingga modern merchant, berdasarkan data yang di peroleh dari hasil wawancara dengan salah satu karyawan Bank DKI, per November 2019 merchant yang sudah di akusisi oleh Bank DKI lebih dari 7.000 merchant yang tersebar di Jabodetabek (Setiawan 2019).

Bila berdasarkan data yang di dapat oleh peneliti grafik pengguna JakOne Mobile terus meningkat setiap bulannya. Pada tahun 2017 pengguna aktif JakOne Mobile sebanyak 35.614 pengguna, pada tahun 2018 meningkat pesat dengan peningkatan jumlah pengguna dengan total 260.931 pengguna (Bank DKI 2018). Pada Desember 2019 terjadi peningkatan jumlah pengguna aktif secara signifikan yaitu mencapai 491.373 pengguna (Bank DKI 2019). Bila dianalisis peningkatan secara signifikan jumlah pengguna JakOne Mobile bertepatan dengan peresmian Taman Jajan JakOne Thamrin 10. Peresmian Taman Jajan JakOne Thamrin 10 menjadi faktor utama peningkatan secara signifikan jumlah pengguna karena konsep yang diusung food and creative park Thamrin 10 yang mengharuskan pembayaran secara cashless sehingga JakOne Mobile menjadi pilihan pertama dalam metode pembayaran di Thamrin 10. Pada Kawasan Thamrin 10, memang pengunjung diharuskan untuk menggunakan sistem pembayaran melalui JakCard ataupun e-wallet. Pembayaran melalu Quick Response (QR) memang dapat menerima pembayaran melalui aplikasi e-wallet selain JakOne Mobile seperti OVO, Dana dan Go-Pay karena QR yang digunakan adalah Quick Response Indonesian Standard (QRIS). QRIS merupakan QR Code yang sudah distandarkan oleh Bank Indonesia sehingga satu barcode dapat melayani pembayaran untuk semua aplikasi e-wallet ataupun mobile banking (Bank Indonesia 2019). Pada Kawasan Thamrin 10 Bank DKI memang menggunakan strategi marketing baik online ataupun offline, segala bentuk jaringan yang relevan dan memanfaatkan segala bentuk media yang dapat digunakan dalam menjangkau sasaran pelanggan dengan memberikan pelanggan paparan iklan secara terus menerus atau dapat disebut dengan 360-degree Branding (A. Shimp, Terence, and J. Craig 2013). 
Fauzia, Firman Kurniawan Sujono: Strategi Branding Jakone Mobile Melalui Sinergi BUMD Taman Jajan Jakone Mobile Thamrin 10

Terhadap peningkatan pengguna JakOne Mobile yang bertepatan dengan peresmian Thamrin 10, peneliti mengambil sampel informan dari penjual, petugas topup dan pengunjung baik yang berlatar belakang masyarakat umum maupun Pegawai Negeri Sipil Provinsi DKI Jakarta untuk melihat seberapa kuat produk JakOne Mobile di mata masyarakat DKI Jakarta. Berdasarkan wawancara dengan penjual di Thamrin 10 Bapak A penjual Es Buah Sinar Garut enyatakan bahwa:

Memang persyaratan awal berjualan di Thamrin 10 bekerjasama dengan Bank DKI terkait sistem pembayaran dan sistem pembayaran hanya menerima scan barcode atau tap JakCard sehingga tidak menerima pembayran melalui tunai (A, komunikasi personal, 29 Desember 2019).

Dari hasil wawancara dengan Bapak A selaku pedagang di Thamrin 10, memang sistem tersebut lebih mudah karena tidak harus menyediakan uang untuk kembalian, akan tetapi masih banyak dari pengunjung yang tidak mengetahui cara pembayaran di Thamrin 10 yang mengusung tema cashless, selain itu masih banyak pengunjung yang tidak memiliki JakCard atau pun JakOne Mobile sehingga penjual mengarahkan pembeli untuk ke booth Bank DKI.

Pada hasil wawancara peneliti dengan petugas booth Bank DKI Sdr. H menyatakan pengunjung dari Thamrin 10 memang tidak seluruhnya paham tentang sistem pembayaran cashless sehingga memang harus dilakukan sosialisasi terlebih dahulu. Banyak dari pengunjung masyarakat umum tidak mengetahui JakOne Mobile sehingga cukup banyak pengunjung yang download dan aktivasi aplikasi tersebut. Sedangkan untuk pengguna JakCard sudah cukup banyak dari pengunjung yang memiliki kartu tersebut sehingga petugas hanya membantu untuk top up JakCard. Menurut Sdr. H, petugas sales tetap menawarkan pengunjung untuk mendownload JakOne Mobile karena ada fitur untuk Top Up JakCard melalui aplikasi tersebut.

Pengunjung dari Thamrin 10 terus meningkat setiap harinya dan berasal dari berbagai lapisan masyarakat dan umur. Berdasarkan wawancara peneliti dengan pengunjung Ibu Ratih (ibu rumah tangga, 46 tahun), beliau mengatakan bahwa memang sedikit kesulitan terkait pembayaran menggunakan aplikasi karena tidak semua orang bisa menggunakan, akan tetapi terkait pemabayaran melalui taping kartu JakCard tidak masalah bagi dirinya, beliau juga mengakui bahwa memang aplikasi JakOne Mobile juga belum pernah menggunakan. Berbeda hal dengan Sdr. Mega (pegawai swasta, 24 tahun) yang menyatakan bahwa:

Inovasi taman jajanan cashless memang sangat menarik, terkait dengan penggunaan JakOne Mobile memang tidak terlalu sering mendengar dan baru menggunakan saat berkungjung ke Thamrin 10 (Mega, komunikasi personal, 29 Desember 2019).

Bahwa pada dasarnnya kehadiran JakOne Mobile memang merubah persepsi masyarakat terhadap Bank Daerah yang dianggap tidak memiliki aplikasi $e$-wallet dan mobile banking. Adapun wawancara peneliti dengan salah satu Pegawai Negeri Sipil Provinsi DKI Jakarta Sdr. S (38 tahun), mengakui sudah menjadi pengguna JakOne Mobile karena payroll PNS DKI melalui Bank DKI, beliau menyatakan: 
Penggunaan JakOne Mobile memang membantu transaksi hariannya baik dari segi transfer, pembayaran tagihan dan transaksi lainnya karena fitur aplikasi yang menggabungkan e-money dan mobile banking dalam satu aplikasi (S, komunikasi personal, 29 Desember 2019).

Bila ditelaah memang penggunaan aplikasi mobile wallet dapat dipengaruhi oleh umur dan lingkungan disekitar mayarakat, hal tersebut membuat mix marketing sangat penting untuk digunakan (Putri, Fajar, and Misnaniarti 2011). Memang banyak dari masyarakat sudah mengkonsumsi informasi melalui perangkat digital akan tetapi pemasaran menggunakan sales dan pemasangan iklan secara offline juga sangat penting dengan menggunakan strategi IMC dengan memberikan pemaparan iklan kepada konsumen secara 360-degree Branding. Dengan IMC semua elemen promosi seperti periklanan, hubungan masyarakat, promosi penjualan, penjualan pribadi, pemasaran langsung, dan pemasaran online / media social berbaur dengan satu sama lain dan dengan elemen lain dari bauran pemasaran merek (produk, tempat, harga) sedemikian rupa sehingga semua elemen berbicara dengan satu suara (Juska 2017). Melalui akusisi transaksi sistem pembayaran pada Thamrin 10 serta memberikan petugas topup dan booth Bank DKI terkait untuk menawarkan dan menjelaskan cara pembayaran di Thamrin 10 membuat produk menjadi lebih dekat dengan konsumen atau dalam lingkup ini adalah pengunjung Thramrin 10, pengunjung dari yang belum mengetahun JakOne Mobile menjadi mengetahui bahkan mengunduh aplikasi, atau pun pengguna JakOne yang semakin memahami manfaat dari penggunaan aplikasi. Sehingga produk knowledge pengguna menjadi bertambah

Strategi penguatan brand yang dilakukan oleh Bank DKI terkait JakOne Mobile memang pada awalnya berupa bekerjasama dengan merchant, program reward seperti cash back dan pembukaan kanal pembayaran yang aplikasi Bank lain atau aplikasi $e$-wallet lain sediakan seperti retribusi daerah dan e-Samsat. Hal tersebut telah menjadi aplikasi pilihan untuk warga Jakarta.

Distribusi memiliki dampak yang besar dalam menciptakan equitas, karena ketika konsumen dapat menemukan produk dengan mudah dan tersedia ketika dibutuhkan (Aaker 1996). Selanjutnya Bank DKI bekerjasama dengan BUMD DKI Jakarta lainnya untuk Thamrin 10 merupakan salah satu strategi yang tepat untuk meningkatkan kekuatan brand baik promosi yang dilaukan melalui media sosial, offline dan sales atau petugas yang berada di Thamrin 10 yang mempromosikan dan membantu topup saldo sehingga ketika masyarakat membutuhkan alat untuk pembayaran petugas langsung membantu. Secara tidak lansung program less cash yang ditepakan di Thamrin 10 memang salah satu cara yang tepat untuk menguatkan brand dari JakOne Mobile karena menjadi pilihan utama dalam sistm pembayaran di Kawasan Thamrin 10. Banyaknya pengunjung yang belum mengetahuin aplikasi tersebut menjadi pengguna baaru aplikasi tersebut.

Dengan adanya aplikasi mobile wallet dan mobile banking menjadi suatu inovasi terbaru bagi perbankan khususnya Bank Daerah yang sering dianggap terlambat dalam hal teknologi. Dengan adanya aplikasi tersebut Bank DKI sudah merubah image Bank Daerah sehingga dapat bersaing dengan Bank BUMN. 
Fauzia, Firman Kurniawan Sujono: Strategi Branding Jakone Mobile Melalui Sinergi BUMD Taman Jajan Jakone Mobile Thamrin 10

\section{Simpulan}

Strategi Bank DKI dalam Branding serta meningaktkan brand equity dari produk mobile wallet dan Mobile Banking Bank DKI yaitu JakOne Mobile dengan cara bekerjasama dengan BUMD DKI Jakarta dalam Taman Jajan JakOne Mobile Thamrin 10 memang cukup efektif. Dimana strategi yang digunakan tidak hanya mengakusisi sistempembayaran sehingga produk Bank DKI yaitu JakOne Mobile menjadi pilihan utama dalam bertransaksi. Bank DKI juga menggunakan strategi mix marketing yang dilakukan di Kawasan Thamrin 10 yaitu dengan mempromosikan melalui sosial media, pemberitaan online dan media cetak, banner pada Kawasan Thamrin 10 dan membuka booth untuk top up serta petugas untuk menjelaskan cara penggunaan aplikasi JakOne Mobile. Dengan strategi tersebut Bank DKI dapat meningkatkan produk knowledge dari pengguna atau new user baik dari segi kemudahan yang ada dalam aplikasi serta petugas di area Thamrin 10 yang dapat membantu menjelaskan manfaat dan cara penggunaan Apliaksi Jakone Mobile. Perlu diperhatikan bahwa untuk mempertahankan suatu kekuatan brand harus didukung dengan brand image yang baik, setiap keritik dan respon tidak baik harus ditangani dengan baik sehingga tidak merusak reputasi yang sudah dibangun.

\section{Ucapan Terima Kasih}

Saya ucapkan terimakasih kepada Tuhan Yang Maha Esa dan Bapak Firman selaku dosen di Pasca Sarjana Ilmu Komunikasi Universitas Indonesia yang sudah meluangkan waktu, memberikan detail materi perkuliahan dan memberikan arahan penulisan sehingga saya dapat menulis jurnal ini.

\section{Daftar Pustaka}

Aaker, D. A. (1996). "Measuring Brand Equity across Products and Markets." California Management Review 38: 102-20.

Amoroso, D. L., and R. Magnier-Watanabe. (2012). "Building a Research Model for Mobile Wallet Consumer Adoption: The Case of Mobile Suica in Japan." Journal of theoretical and applied electronic commerce research 7(1): 94-100.

Bank DKI. (2018). Annual Report Bank DKI 2018. Jakarta.

Bank DKI. (2019). Annual Report Bank DKI 2019. Jakarta.

Bank Indonesia. (2019). "QRIS, Satu QR Code Untuk Semua Pembayaran." bi.go.id. https://www.bi.go.id/id/ruang-media/siaranpers/Pages/SP_216219.aspx (January 1, 2020).

BankDKI. (2017). "Bank DKI Luncurkan JakOne Mobile.” bankdki.co.id.

Boomsma, Marije, and Michiel Arnoldus. (2008). Branding for Development. Amsterdam: KIT Working Papers.

Dawar, N., and P Parker. (1994). “Marketing Universals: Consumers' Use of Brand Name, Price, Physical Appearance, and Retailer Reputation as Signals of Product Quality." Journal of Marketing 58(2): 81-95. 
Devita, Vivin Dian. (2019). "Siapa Aplikasi E-Wallet Dengan Pengguna Terbanyak Di Indonesia?" iprice.

EQ. (2019). "Bank DKI Targetkan Pengguna JakOne Mobile Tembus 1 Juta Orang Tahun Ini." Propertynbank.com.

Huber, Frank, Alan T. Shao, and Yeqing Bao. (2007). "Building Brand Equity via Product Quality." Taylor \& Francis e-Library 18(5): 531-44.

"Informasi Perizinan Penyelenggara Dan Pendukung Jasa Sistem Pembayaran." 2019. www.bi.go.id. https://www.bi.go.id/id/sistem-pembayaran/informasiperizinan/uang-elektronik/penyelenggara-berizin/Pages/default.aspx (July 27, 2019).

JSC. (2017). "Dibalik Cita-Cita Cashless Society, Kenapa Harus Non Tunai?" Jakarta Smart City.

Juska, Jerome M. (2017). Integrated Marketing Communication: Advertising and Promotion in a Digital World. Routledge.

Keller, Kevin Lane. (2003). Strategic Brand Management: Building, Measuring, and Managing Brand Equity. New Jersey: Prentice Hall.Inc.

Kompas.com. (2019). "10 Layanan Dompet Digital Di Indonesia, Siapa Paling Populer?" tekno.kompas.com. https://tekno.kompas.com/read/2019/08/27/14240047/10-layanan-dompetdigital-di-indonesia-siapa-paling-populer?page=all.

Kotler, and Keller. (2009). Manajemen Pemasaran. Jakarta: Erlangga.

Kotler, Philip. (2003). Marketing Management. 11th ed. New Jersey: Prentice Hall.Inc.

Neuman, W.Laurence. (2016). Metodologi Penelitian Sosial: Pendekatan Kualitatif Dan Kuantitatif. Jakarta: PT. Indeks.

Nurfaiza, Ellena. (2012). “Analsisi Peran Program Corporate Social Responsibility (CSR) Dalam Membangun Corporate Reputation, Brand Equity Dan Social Euity Brand: Studi Kasus Pada Merek Lifebuoy Produk Dari PT. Unilever.” Universitas Indonesia.

Oktavianti, Roswita, and Budi Utami. (2019). "Strategi Mempertahankan Brand Knowledge Program Televisi Seputar Indonesia Di RCTI." Jurnal Komunikasi Untar: 81-91.

Peter, and Olson. (2000). Pengertian Kesadaran Merek. Jakarta: Erl.

Putri, Prima Sari, Nur Alam Fajar, and Misnaniarti. (2011). "Penerapan Marketing Mix Melalui Pemanfaatan Pelayanan Kesehatan Di Poliklinik Kebidanan Dan Kandungan Rumah Sakit Ar Bunda Prabumulih." Jurnal Ilmu Kesehatan Masyarakat 2.

Rossiter, J. R, and L. Percy. (1987). Advertising and Promotion Management. New York: McGraw Hill.

Setiawan, Sakinah Rakhma Dian. (2019). "Milenial Jakarta Di Bidik Jadi Pengguna JakOne Mobile." Kompas.com.

Shimp, A., Terence, and Andrews J. Craig. (2013). Advertising, Promotion, and Other Aspects of Integrated Marketing Communications. Cengage Learning.

Shimp, Terence A. (2003). Advertising, Promotion \& Supplemental Aspects of Integrated Marketing Communications. 6th ed. Thomson South-Western. 
Fauzia, Firman Kurniawan Sujono: Strategi Branding Jakone Mobile Melalui Sinergi BUMD Taman Jajan Jakone Mobile Thamrin 10

Silaen, Elsa, and Bulan Prabawani. (2019). "Pengaruh Persepsi Kemudahan Menggunakan E-Wallet Dan Persepsi Manfaat Serta Promosi Terhadap Minat Beli Ulang Saldo E-Wallet OVO.” Jurnal Ilmu Administrasi Bisnis 9.

Suri, Dharlinda. (2019). "Pemanfaatan Media Komunikasi Dan Informasi Dalam Perwujudan Pembangunan Nasional." Jurnal Komunikasi Pembangunan 19. 